\title{
Anthropogenic 129l in the sediment cores in the East China sea Sources and transport pathways
}

Zhao, Xue; Hou, Xiaolin; Du, Jinzhou; Fan, Yukun

\section{Published in:}

Environmental Pollution

Link to article, DOI:

10.1016/j.envpol.2018.11.018

Publication date:

2019

Document Version

Peer reviewed version

Link back to DTU Orbit

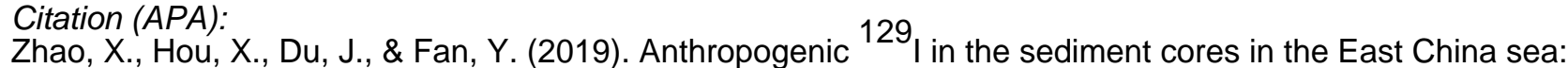
Sources and transport pathways. Environmental Pollution, 245, 443-452.

https://doi.org/10.1016/j.envpol.2018.11.018

\section{General rights}

Copyright and moral rights for the publications made accessible in the public portal are retained by the authors and/or other copyright owners and it is a condition of accessing publications that users recognise and abide by the legal requirements associated with these rights.

- Users may download and print one copy of any publication from the public portal for the purpose of private study or research.

- You may not further distribute the material or use it for any profit-making activity or commercial gain

- You may freely distribute the URL identifying the publication in the public portal

If you believe that this document breaches copyright please contact us providing details, and we will remove access to the work immediately and investigate your claim. 


\section{Anthropogenic ${ }^{129} \mathrm{I}$ in the sediment cores in the East China}

2

4 a. State Key Laboratory of Loess and Quaternary Geology, Xi'an AMS Center, Institute of Earth

5 Environment, Chinese Academy of Sciences, Xi'an 710061, Shaanxi Key Laboratory of Accelerator

6 Mass Spectrometry Technology and Application, P. R. China

7

8

9

\author{
Xue Zhao ${ }^{\mathrm{a}, \mathrm{e}}$, Xiaolin Hou ${ }^{\mathrm{a}, \mathrm{b}, \mathrm{d}^{*}}$, Du Jinzhou ${ }^{\mathrm{c}}$, Yukun Fan ${ }^{\mathrm{a}}$
}

b. Center for Nuclear Technologies, Technical University of Denmark, Risø Campus, Roskilde 4000,

Denmark

c. State Key Laboratory of Estuarine and Coastal Research, East China Normal University, Shanghai 200062, P. R. China

d. Open Studio for Oceanic-Continental Climate and Environment Changes, Pilot National Laboratory for Marine Science and Technology (Qingdao), Qingdao 266100, P. R. China

e. University of Chinese Academy of Sciences, Beijing 100049, P. R. China

ABSTRACT: With the increased numbers of nuclear power plants constructed along the east coast of China, improved knowledge of radioactive sources and transport through different pathways between land and sea is needed. ${ }^{129} \mathrm{I}$ and ${ }^{127} \mathrm{I}$ in two sediment cores from the East China Sea were analyzed. The chronology by excess ${ }^{210} \mathrm{~Pb}$ from two sediment cores was determined to cover the range of 1959-2010. Significantly increased levels $\left({ }^{129} \mathrm{I} /{ }^{127} \mathrm{I}=(15.0-75.0) \times 10^{-12}\right)$ compared to the pre-nuclear value $\left({ }^{129} \mathrm{I} /{ }^{127} \mathrm{I}\right.$ $=1.5 \times 10^{-12}$ ) were observed, with peaks in layers of 1959, 1966, 1971 and 1976 (1977) corresponding to the atmospheric nuclear weapon tests at Pacific Proving Grounds and Lop Nor, and with high values after the late 1970s related to the European reprocessing plants releases, of which the reprocessing

\section{Sea: sources and transport pathway}

\footnotetext{
${ }^{*}$ Corresponding author at: No. 97 Yanxiang Road, Yanta District, Xi'an, Shaanxi Province, 710061, China E-mail address: houxl@ieecas.cn (X. Hou).
} 
22 releases dominate the total amount of ${ }^{129} \mathrm{I}$. In addition to ocean current transport, the combined action

23 of Westerlies with Monsoon is an important driving force of large-scale pollutant dispersion from high

24 latitude West Europe to middle latitude East Asia. Riverine input is the main pathway for the transport

25 of radioactive pollutants from Lop Nor to the sea.

\section{Capsule:}

28 The sources and transportation pathway of anthropogenic ${ }^{129} \mathrm{I}$ in the ECS was investigated to evaluate the impact of the human nuclear activities and improve the understanding of pollutant dispersion.

31 Keywords: Iodine-129; sediment; Environmental dispersion; human nuclear activities; Lop Nor;

\section{Introduction}

Anthropogenic pollutants released into the environment can be preserved in terrestrial and marine system through atmospheric dispersion and deposition, precipitation leaching and riverine input, and sea currents transport. Enhancing knowledge on sources and transport pathways of pollutants is crucial. A large amount of radioactive substances have been released from human nuclear activities through atmospheric nuclear weapon tests (NWTs), nuclear accidents (NA) and the reprocessing of spent nuclear fuel (NFRPs) (UNSCEAR 2000). ${ }^{129} \mathrm{I}$ as a fission product of ${ }^{235} \mathrm{U}$ and ${ }^{239} \mathrm{Pu}$ has already entered the environment (Hou et al., 2013). Up to 2013, over $6500 \mathrm{~kg}$ of ${ }^{129} \mathrm{I}$ has been released from NFRPs mainly in Sellafield, La Hague and Marcoule, $150 \mathrm{~kg}$ from NWTs and $7.2 \mathrm{~kg}$ from NA (totality of Chernobyl and Fukushima), which highly overwhelmed the natural inventory of ${ }^{129} \mathrm{I}$ in surface environment (180 kg in hydrosphere, $60 \mathrm{~kg}$ in lithosphere, most exists in the ocean, with a natural ${ }^{129} \mathrm{I} /{ }^{127} \mathrm{I}$ atomic ratio of $1.5 \times 10^{-12}$ ) (Moren et al., 1998). Owing to the long half-life (15.7 Ma) of ${ }^{129} \mathrm{I}$, high volatility and water solubility, conservative feature in the ocean, biophile characteristics and redox sensitivity of iodine, ${ }^{129}$ I entered into both terrestrial and marine systems and can now be used as an environmental tracer in investigation of atmospheric dispersion of European NFRPs originated 
47 pollutant (Moran et al., 1999), re-emission of ${ }^{129}$ I from the contaminated seawater by NFRPs (Sellafield 48 and La Hague) to the atmosphere (Hou et al., 2009a), dispersion of Fukushima pollutants in North 49 Pacific Ocean (Stan-Sion et al., 2015; Chang, 2016), the circulation of California Current System and 50 the background value under the influence of Hanford site (Chang, 2016), and the long-term transfer 51 process of radioiodine from soil to the plant and translocation within soil in Chernobyl contaminated 52 surface (Handl et al., 1990).

53 Sediments can be ideal integrated archives of sequential environment signals from atmosphere, 54 biosphere, pedosphere and hydrosphere, which could supply radioactive sources information and trace 55 the relative transportation processes based on the temporal distributions of ${ }^{129} \mathrm{I}$ in both marine and 56 terrestrial environment. The marine current circulation from North Sea to Baltic Sea through the 57 Skagerrak and Kattegat was identified by liquid discharges from Sellafield and La Hague, and the 58 variation trend was constructed by analyzing the temporal distribution of ${ }^{129} \mathrm{I}$ in Baltic Sea sediment 59 (Aldahan et al., 2007). The process of close-in tropospheric bomb fallout from Nevada site that eroded 60 from drainage basin was traced based on the vertical profile of ${ }^{129} \mathrm{I} /{ }^{127} \mathrm{I}$ in Mississippi Delta sediments 61 (Oktay et al., 2000). The low-latitude gaseous pollutant transportation from PPG to the central 62 Philippines through trade winds was determined from the ${ }^{129} \mathrm{I}$ distribution in a lake sediment core 63 collected in the Philippines (Zhang et al., 2018). However, the transport and pathway of radioactive 64 pollution between the terrestrial and marine system is still not well known, especially the transport 65 pathway of atmospheric deposition on the ground into the marine system. Sediment cores from 66 epicontinental seas are the ideal choices for the study of the dynamics of transport from the land to the 67 sea. Our previous investigation on ${ }^{129} \mathrm{I}$ in a sediment core collected in Jiaozhou Bay, located in the margin sea of the Yellow Sea, clearly showed signals from different nuclear activities (Fan et al., 2016).

69 Such kinds of investigations were not undertaken in the East China Sea (ECS) margin until April 2018, 70 although the most important area for pollutant dispersion research, since 39 nuclear power reactors are 71 installed nearby.

72 This work aims to investigate the sources and pathways of radioactive pollution in the margin of the 73 ECS by determination of ${ }^{129}$ I distribution in two sediment cores collected there in 2010 . The results will 
74 also provide important data for evaluation the impact of different types of human nuclear activities on

75 the marine environment, and for understanding pollutant dispersion model in the case of accidents.

\section{2. Material and methods}

\section{$77 \quad 2.1$ Study area}

The ECS is a broad and shallow epicontinental sea between mainland China in the west, the Taiwan

79 Strait in the south, and the Yellow Sea in the north. Water circulation in the ECS is dominated by 80 oceanic intrusions of the northward Kuroshio Current (KC) and Taiwan Warm Current (TWC), 81 southward flow of the Yellow Sea Coastal Current (YSCC)) and mostly eastward flow of the 82 Changjiang Dilute Water (CDW) (northeastward in summer and southward or southeastward in winter under the control of East Asian Monsoon) (Sasaki et al., 2008) (Fig. 1). The TWC after entering the

84 ECS is divided into two branches, with one to the southeast and another mingling with CDW. The CDW

85 with low salinity moves along the surface $10 \mathrm{~m}$, carries large amount of fresh water (mean: $9.05 \times 10^{11}$ $86 \mathrm{~m}^{3} \mathrm{y}^{-1}$ ) and sediment (mean: $2.4 \times 10^{8}$ ton $\mathrm{y}^{-1}$ ) to the ECS from the Changjiang (Yangtze) River (Liu et 87 al., 2007). In the north of the Changjiang Estuary, there is the southeastwards Yellow Sea Coastal Current (YSCC) driven by the winter monsoon to penetrate into the northern ECS, which remains steady

89 from October to next July, and disappears in August and September (Li et al., 2006). The north part of 90 YSCC water consists of the Liaonan Coastal Current and Lubei Coastal Current, which takes in the 91 fresh water input mainly from nearby Liao River and Yellow River to transport them out of the Bohai 92 Sea, and then moves southwards after crossing the east most of Shandong Peninsula to the south of $30^{\circ}$ $93 \mathrm{~N}$ (Wei et al., 2011). The YSCC meets the CDW in the border $\left(30^{\circ} \mathrm{N}\right)$ of the Yellow Sea and ECS with 94 loading material to ECS ( $\mathrm{Li}$ et al., 2006), and formatting a converging zone around $30^{\circ} \mathrm{N}, 126^{\circ} \mathrm{E}$ (Fig. $951)$. 


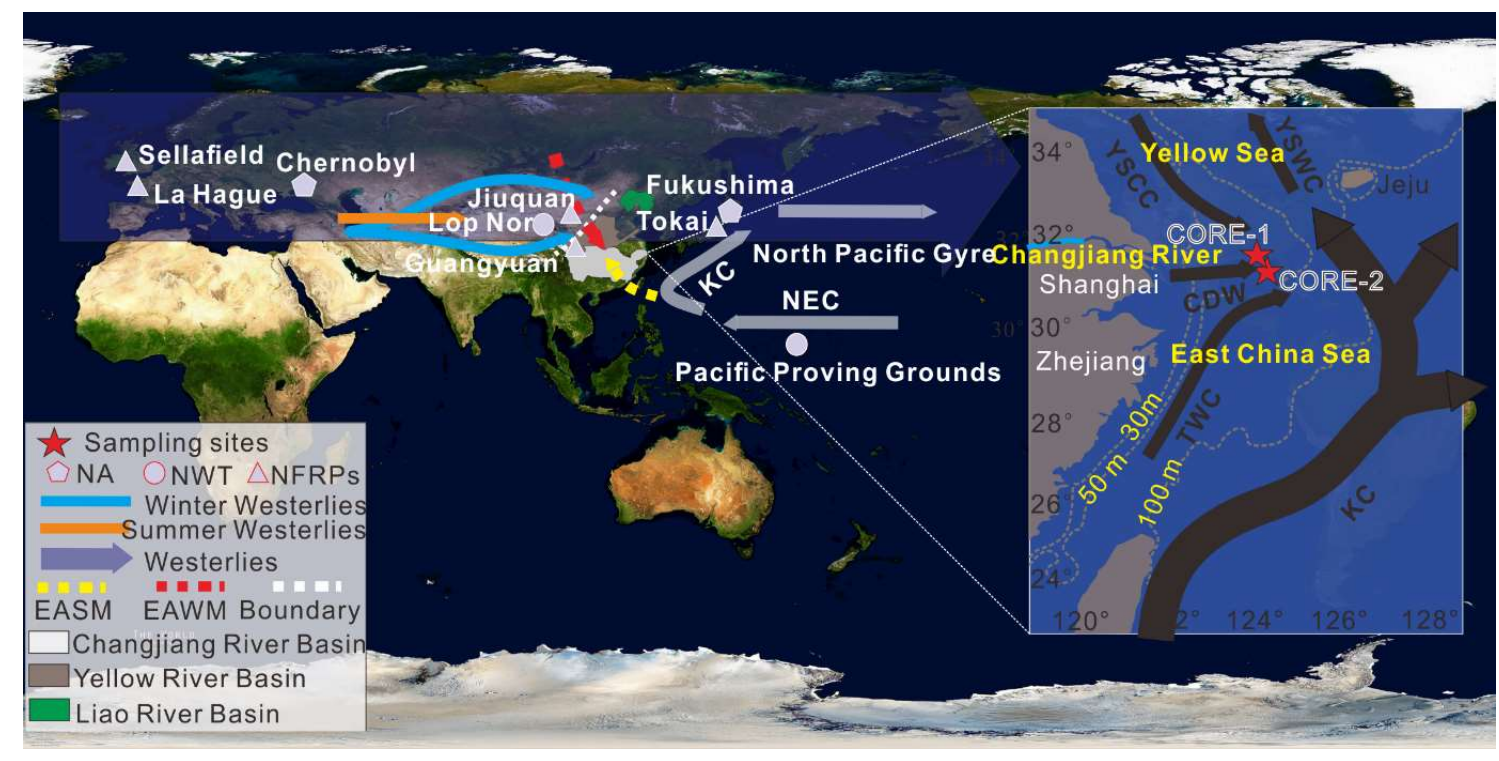

Fig. 1. Sampling site of two sediment cores with possible sources, the major sea currents in the East China Sea and the dominant wind direction in China (Wang et al. 2017, Chen et al., 2009). NA, Nuclear Accident; NWT, Nuclear Weapon Test; NFRPs, Nuclear Fuel Reprocessing Plants; EASM, East Asian summer monsoon; EAWM, East Asian winter monsoon; NEC, North Equatorial Current; KC, Kuroshio Current; YSCC, Yellow Sea Coastal Current; YSWC, Yellow Sea Warm Current; CDW, Changjiang Dilute Water. TWC, Taiwan Warm Current; The dashed-line boundary stands for the dividing line of monsoon region and westerly area. Sampling sites mainly receive fresh water from Yangtze River, Yellow River and Liao River through CDW and YSCC, and sea water from TWC, also is controlled by East Asian Monsoon.

The ECS shelf is located in the intense region of the East Asia Monsoon. The year prevailing wind direction is from the southeast with strong rainfall in summer and from the northwest featured with dry and cold in winter. The total riverine input would go further into the middle and outer shelf of ECS during stronger dry northwest winter monsoons, leading more sediment is moved towards the southeast (Fig. 1)

\subsection{Material and core chronology}

The two sediment cores, CORE-1 of $19 \mathrm{~cm}\left(31.5^{\circ} \mathrm{N}, 124.51^{\circ} \mathrm{E}\right)$ and CORE-2 of $22 \mathrm{~cm}\left(30.99^{\circ} \mathrm{N}\right.$, $124.99^{\circ} \mathrm{E}$ ), were sampled near the 50m depth contour in the ECS (Fig.1) in Jun 2010. The sampling sites were situated in the converging region formed by YSCC, CDW and TWC (Wang et al., 2017). The sediment cores were sampled with 10-cm diameter Plexiglas Core Tubes and were sliced into 1$\mathrm{cm}$ interval and then stored at $4{ }^{\circ} \mathrm{C}$ until laboratory analysis. The sliced sediment samples were first freeze-dried, and then ground and sieved through a 200-mesh sieve. After weighing and transferring the samples to a plastic counting container, the activities of ${ }^{210} \mathrm{~Pb}$ were measured using HPGe gamma spectrometry (Canberra Be3830) with 35\% relative counting efficiency to determine the accumulation 
rate of CORE- 1 is $0.37 \pm 0.01 \mathrm{~cm} / \mathrm{a}$ and CORE- 2 is $0.42 \pm 0.01 \mathrm{~cm} / \mathrm{a}$, and the detail of dating method was described in the Supplementary Information 1 (Wang et al., 2017). Both accumulation rates fall in the similar level with reported values in this area (Wang et al., 2017), which corresponds to the pattern that high accumulation rate is found in the southeast, driven by strong northwest winter monsoons, as discussed above. 19 samples of CORE-1 from depth of 0-19 cm corresponding to 1960-2010, and 22 samples of CORE-2 from depth of 0-22 cm corresponding to 1959-2010 were selected for iodine isotopes analysis. The time range of $1 \mathrm{~cm}$ is 2.7 years for CORE-1 and 2.4 years for CORE-2, which suggests the age uncertainty for the entire profiles might be up to 3 years.

\subsection{Determination method of iodine isotopes in the sediment}

All the details of chemical reagents used here are described in the Supplementary Information 2. The iodine in the sediment was separated by combusting at $800{ }^{\circ} \mathrm{C}$ for 3 hours in a tube furnace (Catalytic Pyrolyser-4 TrioTM furnace, Raddec LTD, Southampton, UK). The detail analytical method has been reported elsewhere and is summarized in the Supplementary Information 2 (Hou et al., 2010). The measurement of ${ }^{129} \mathrm{I} /{ }^{127} \mathrm{I}$ atomic ratios was conducted using a 3 MV Tandem AMS system (HVEE) at Xi' an AMS Center, China, and the details of AMS system and measurement method for ${ }^{129} \mathrm{I}$ have also been reported elsewhere (Hou et al., 2010). The measured ${ }^{129} \mathrm{I} /{ }^{127} \mathrm{I}$ ratios in procedure blank were below $2 \times 10^{-13}$, which was at least 2 orders of magnitude lower than that in samples. The ${ }^{129} \mathrm{I} /{ }^{127} \mathrm{I}$ ratios in the samples were corrected by subtracting the blank. The stable iodine was measured using ICP-MS (Agilent 8800 ICP-MS) at the Xi' an AMS Center. $\mathrm{Cs}^{+}$was added as internal standard, $0.15 \mathrm{~mol} / \mathrm{L}$ $\mathrm{NH}_{3} \cdot \mathrm{H}_{2} \mathrm{O}$ is used as wash solution between samples. The detection limit of this method is lower than magnitude lower than the samples. 


\section{Result}

141

142

143

144

\section{1 ${ }^{127}$ I and ${ }^{129}$ I level in the sediment cores from the ECS}

The analytical results of ${ }^{127} \mathrm{I}$ and ${ }^{129} \mathrm{I}$ in the two sediment cores show that the ${ }^{127} \mathrm{I}$ concentrations are 5.0-37.2 $\mu \mathrm{g} / \mathrm{g}$ in CORE-1 and 15.0-42.5 $\mu \mathrm{g} / \mathrm{g}$ in CORE-2 (Fig. 2). The iodine in marine sediment mainly originates from decomposition of biota debris with high iodine content (marine algae: 10-6000 $\mu \mathrm{g} / \mathrm{g}$, most values: $200-300 \mu \mathrm{g} / \mathrm{g}$, mineral $<1 \mu \mathrm{g} / \mathrm{g}$ ), which absorbs and concentrates iodine from seawater (around $50 \mu \mathrm{g} / \mathrm{L}$ ) (Hou et al., 2010; Hou et al., 1998; Price and Calvert, 1973). The ${ }^{127} \mathrm{I}$ concentrations in CORE-1 $(5.0-37.0 \mu \mathrm{g} / \mathrm{g})$ and CORE-2 $(15.0-42.5 \mu \mathrm{g} / \mathrm{g})$ is lower than that in most marine sediments, including those from Oregon $(98-243 \mu \mathrm{g} / \mathrm{g})$, Kattegat $(100-200 \mu \mathrm{g} / \mathrm{g})$ and Baltic Sea (42.7-75.9 $\mu \mathrm{g} / \mathrm{g}$ ) (Moran et al. 1998; López-Gutiérrez et al., 2004; Aldahan et al., 2007), but higher than most values of lake sediments collected from Sweden (5.0-10.0 $\mu \mathrm{g} / \mathrm{g})$ and Philippines $(2.97-20 \mu \mathrm{g} / \mathrm{g})$ (Englund et al., 2008; Zhang et al., 2018). The values are in the similar level with that in the mixed zone of river and ocean, such as Jiaozhou Bay $(20-36 \mu \mathrm{g} / \mathrm{g})$ and the Mississippi River Delta (5.7-34.3 $\mu \mathrm{g} / \mathrm{g})$ (Fan et al., 2016; Oktay et al., 2000) (Table SI2). This indicates that the sampling sites are located in the mixed zone of river and ocean input.

Large variation of ${ }^{129}$ I concentrations were observed in the two sediment cores, i.e. $(0.05-1.2) \times 10^{7}$ atoms $/ \mathrm{g}$ in CORE-1 and (0.13-1.2) $\times 10^{7}$ atoms/g in CORE-2 (Fig. 2). More than one order of magnitude differences in ${ }^{129}$ I concentrations in the two depth profiles should be attributed to the different sources of ${ }^{129} \mathrm{I}$ accumulated in the sediment cores. The high variation might also result from the variation of iodine into the sediment in different period. To overcome the influence of different input and integration of iodine, the ${ }^{129} \mathrm{I} /{ }^{127} \mathrm{I}$ atomic ratio is often used to investigate the source of ${ }^{129} \mathrm{I}$. The ${ }^{129} \mathrm{I} /{ }^{127} \mathrm{I}$ atomic ratios of $(17-65) \times 10^{-12}$ for CORE-1, and (15-66) $\times 10^{-12}$ for CORE-2 are more than one order of magnitude higher than the pre-nuclear level of ${ }^{129} \mathrm{I} /{ }^{127} \mathrm{I}$ ratios in marine system $\left(1.5 \times 10^{-12}\right)$ (Moran et al., 1998), indicating the ${ }^{129} \mathrm{I}$ in the sediment cores is mainly due to anthropogenic sources. However, this level is more than 2 orders of magnitude lower than that in marine sediments collected from directly affected area by reprocessing releases in Europe $\left(10^{-8}-10^{-9}\right)$ (López-Gutiérrez., 2004; Aldahan et al., 
167 Sweden $\left(10^{-9}-10^{-8}\right)$ and Spain $\left(10^{-11}-10^{-9}\right)$ (Englund et al., 2008; Santos et al., 2007). This result is 168 comparable to the ${ }^{129} \mathrm{I} /{ }^{127} \mathrm{I}$ ratios reported in sediment cores from East Asia, such as Jiaozhou Bay in Yellow Sea $\left(10^{-12}-10^{-10}\right)$ and Taal lake in Philippines $\left(10^{-12}-10^{-10}\right)$ (Fan et al., 2016; Zhang et al., 2018), indicating it falls to the present background level without direct influence from the nuclear facilities

\section{1 (Table SI2).}

\subsection{Distributions of ${ }^{127} I$ and ${ }^{129} I$ concentrations in the two sediment cores}
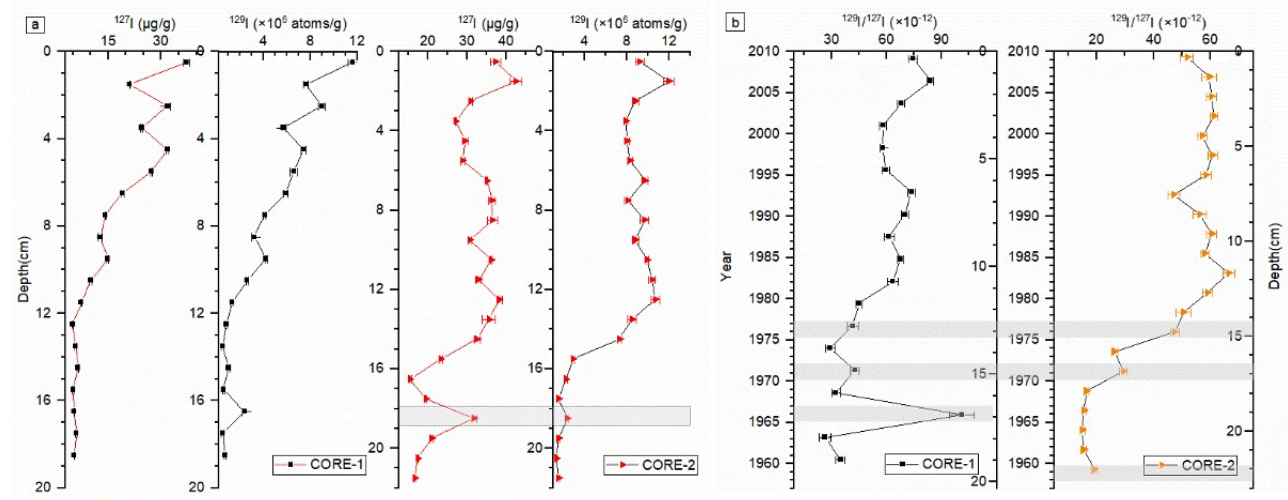

173

174

175

176

177

178

179

180

181

182

183

184

185

186

187

Fig. 2. Depth profiles of ${ }^{127} I$ and ${ }^{129} I$ concentrations and in sediment CORE-1 and CORE-2 from the ECS (a). Depth profiles of ${ }^{129} \mathrm{I} /{ }^{127} \mathrm{I}$ atomic ratios within time in CORE-1 and CORE-2 collected in ECS (b). More drastically decreased ${ }^{127} \mathrm{I}$ along depth occurs in CORE-1. There is a less positive correlation between ${ }^{129} \mathrm{I}$ and ${ }^{127} \mathrm{I}$ concentrations in CORE-2 than CORE-1. Two synchronous peaks show in two cores around1972 and 1976/1977, and a separate peak in 1966 found in CORE-1 and a distinct small high value around 1959 in CORE-2.

The depth profiles of ${ }^{127} \mathrm{I}$ and ${ }^{129} \mathrm{I}$ concentrations in the two sediment cores shows a gradually decreasing ${ }^{127} \mathrm{I}$ concentration from the top to about $12 \mathrm{~cm}$ in CORE-1 and then remaining at a constant low value of about $5.5 \mu \mathrm{g} / \mathrm{g}$ in 13-21 cm (Fig. 2 a). A different distribution was observed in CORE-2 with a relative constant and high ${ }^{127} \mathrm{I}$ concentration of $27-42 \mu \mathrm{g} / \mathrm{g}$ occurring in depth $0-15 \mathrm{~cm}$, and then slightly deceasing to $15-32 \mu \mathrm{g} / \mathrm{g}$ in the depth of $16-22 \mathrm{~cm}$, which is still higher than that in the deeper part of CORE-1 (Fig. 2 a). The difference of ${ }^{127}$ I depth profile between two cores might be induced by different deposition environments that often take place due to the rugged sea floor. Then the fluctuation of ${ }^{127} \mathrm{I}$ concentration along profile probably indicates the material source changing with time in a convergent zone comprised of CDW, YSCC and some TWC origin.

The significantly positive correlation between ${ }^{129} \mathrm{I}$ and ${ }^{127} \mathrm{I}$ concentrations in CORE-1( $\mathrm{r}=0.97, \mathrm{P}<$ 0.01 ) indicates that ${ }^{129} \mathrm{I}$ and ${ }^{127} \mathrm{I}$ in the sediment have the same sources. However, the correlation between 
${ }^{129} \mathrm{I}$ and ${ }^{127} \mathrm{I}$ in CORE-2 is less significant as that in CORE-1, especially in the deep layer of the sediment core (top $16 \mathrm{~cm}: \mathrm{r}=0.81, \mathrm{P}<0.01,16-22 \mathrm{~cm}: \mathrm{r}=0.50, \mathrm{P}<0.01$ ). This discrepancy might imply different sources of ${ }^{129} \mathrm{I}$ and ${ }^{127} \mathrm{I}$. Apart from directly atmospheric deposition, ${ }^{129} \mathrm{I}$ in marine sediment is also derived from marine organisms, which absorb ${ }^{129}$ I (iodine) from seawater during their lifetime. CORE1 is located at the area with high concentration of riverine input from CDW and YSCC, which could supply both ${ }^{127} \mathrm{I}$ and ${ }^{129} \mathrm{I}$, causing a significantly positive correlation between ${ }^{129} \mathrm{I}$ and ${ }^{127} \mathrm{I}$ in CORE-1 . Due to the longer distance to the coast, a relative constant and high ${ }^{127} \mathrm{I}$ concentration was found in CORE-2 that implied more seawater input, while ${ }^{129} \mathrm{I}$ in this estuary area with the depth of only $50 \mathrm{~m}$ is mainly from riverine input as demonstrated by the declined trend of ${ }^{129} \mathrm{I}$ levels in surface seawater from the Changjiang River estuary towards the ECS shelf (Liu et al., 2016).

Although the depth profiles of ${ }^{127} \mathrm{I}$ and ${ }^{129} \mathrm{I}$ concentrations show differences in the two cores, the

${ }^{129} \mathrm{I} /{ }^{127} \mathrm{I}$ atomic ratios profiles in the two cores (Fig. 2 b) are similar, with relatively high and constant ${ }^{129} \mathrm{I} /{ }^{127} \mathrm{I}$ ratios $\left((50-70) \times 10^{-12}\right)$ in the upper $11-13 \mathrm{~cm}$, followed by a dramatically decreased ratios down to $15 \times 10^{-12}$ at the bottom. Meanwhile, several peaks in the lower part of two cores (before 1980) can be observed, which correspond to the years 1966, 1971, 1977 respectively in CORE-1, and 1959, 1971, 1976 in CORE-2. The slight time discrepancy between the two cores might be ascribed to the uncertainty of chronology. The missing peak around 1958-1961 in CORE-1 is attributed to the short length of $19 \mathrm{~cm}$ in CORE-1. The lack of a peak around 1966 in CORE-2 possibly is caused by the doubled ${ }^{127}$ I concentration (Fig. 2 b). It is obvious that the deepest layers of both cores do not reach to the pre-nuclear age (before 1945), which restricts the discussion about pre-nuclear level of ${ }^{129} \mathrm{I}$ level in the ECS.

\section{Discussion}

\subsection{Sources and pathways of ${ }^{129} I$ in the sediment in the ECS}

The anthropogenic ${ }^{129} \mathrm{I}$ in the ECS can potentially originate from (1) fallout of the atmospheric nuclear weapon tests (NWT) in 1945-1980; (2) releases of the Chernobyl nuclear accidents in 1986 and 


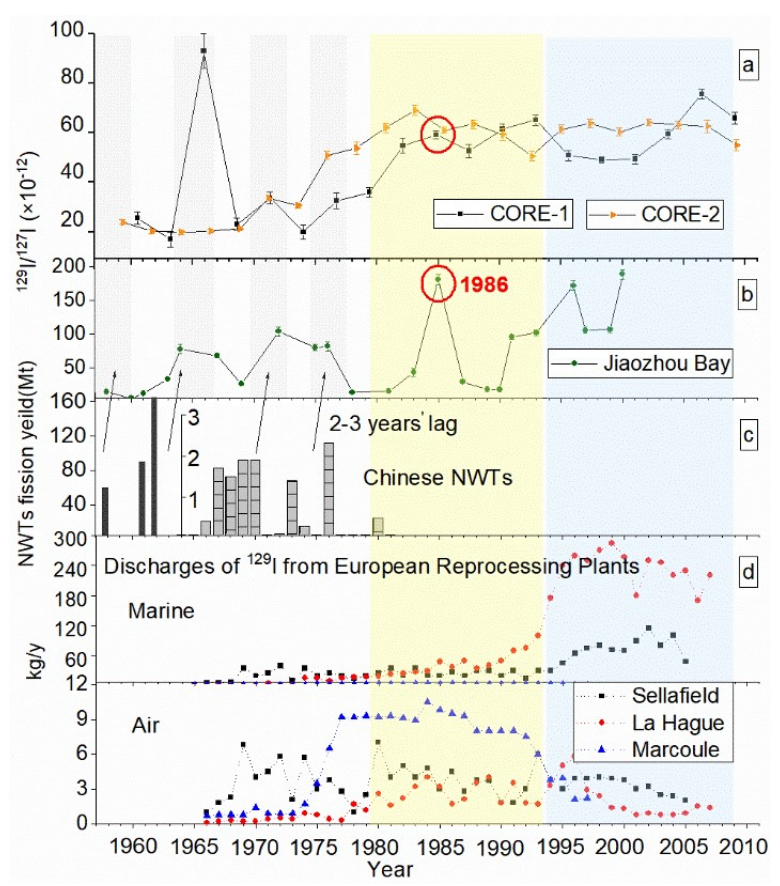

Fig. 3. Comparison of measured ${ }^{129} \mathrm{I} /{ }^{127} \mathrm{I}$ ratios in the sediment cores from ECS (a) with that from Jiaozhou Bay sediment (b) (Fan et al., 2016), NWT fission yield (c) (UNSCEAR 2000), marine discharges and air discharges of ${ }^{129}$ I from NFRPs (d) (Hou et al., 2009b). The first 1959 peak in CORE-2 and Jiaozhou Bay corresponds to the NWTs around 1958; The second peak equals to the NWTs in 1961-1962; The next two peaks relate to two periods of Chinses NWTs; The high ${ }^{129} \mathrm{I} /{ }^{127} \mathrm{I}$ ratios since late 1970 s correspond to NFRPs release.

\subsection{1 ${ }^{129}$ I from PPG (Pacific Proving Grounds) by ocean current}

The first high ${ }^{129} \mathrm{I} /{ }^{127} \mathrm{I}$ value $\left(19.2 \times 10^{-12}\right)$ at $22 \mathrm{~cm}(1959)$ compared to the nearby values $\left(15 \times 10^{-}\right.$

${ }^{12}$ ) in $18-21 \mathrm{~cm}$ from CORE-2 might indicate ${ }^{129} \mathrm{I}$ input from atmospheric NWTs. Due to a global atmospheric fallout lag of about 1-2 years (Zhang et al., 2018), the hysteresis quality of marine sediment record and the uncertainty of chronology (maximum \pm 3 years), the NWTs during 1956-1958 (19591960 is the moratorium period) should be considered (Fig. 3 c). Since the 2-times higher fission yield at PPG (27.63 Mt) than the total yield (14.78 Mt) of other tests (Nevada, Novaya Zemlya and

233 Semipalatinsk) during this period and the relatively short distance $(4700 \mathrm{~km})$ to the sampling sites, the 
2000). Apart from global fallout of the NWTs at PPG, the high water soluble ${ }^{129}$ I from relatively high local deposition could enter into the seawater and then be transported to the ECS through the North Equatorial Current (NEC) and then the Kuroshio (Fig. 1 North Pacific Gyre). Many observations on anthropogenic radionuclides in the West Pacific have indicated sources from the NWTs at PPG, such as ${ }^{129}$ I peak in 1959 in coral samples collected in the South China Sea (Chang et al., 2016; Bautista et al., 2016), plutonium isotopes in sediment cores collected from the ECS (Wang et al., 2017), Pearl River Estuary (Wu et al., 2014), and even a peak of ${ }^{129} \mathrm{I}$ in 1957 in sediment from Jiaozhou Bay (Yellow Sea, China), further north of the study area (Fan et al., 2016).

\subsection{2 ${ }^{129}$ I source from NWTs during 1960-1980}

The maximum ${ }^{129} \mathrm{I} /{ }^{127} \mathrm{I}$ peak $\left(93.0 \times 10^{-12}\right)$ appears at the depth of $17 \mathrm{~cm}$ in CORE-1 corresponding to 1966 , and the same peak of ${ }^{129} \mathrm{I}$ concentration $\left(2.3 \times 10^{6}\right.$ atoms $\left./ \mathrm{g}\right)$ is presented in $19 \mathrm{~cm}$ corresponding to 1966 in CORE-2 even without a ${ }^{129} \mathrm{I} /{ }^{127} \mathrm{I}$ peak which is obscured by the almost twofold of ${ }^{127} \mathrm{I}$ concentration $(31.8 \mu \mathrm{g} / \mathrm{g})$ than the adjacent ones $(19.4 \mu \mathrm{g} / \mathrm{g})$ (Fig. $2 \mathrm{a})$. The global fallout of the largest numbers of atmospheric NWTs in 1961-1962 should response for this peak (Fig. 3 c), and the 4 years' lag is explained by the uncertainty of chronology, the long sweep time from stratosphere and the hysteresis quality of marine sediment record. A similar ${ }^{129} \mathrm{I}$ peak at this period was also observed in sediment from Jiaozhou Bay in Yellow Sea (Fan et al., 2016) and coral samples from South China Sea (Chang et al., 2016). In addition, the signal was recorded by a ${ }^{137} \mathrm{Cs}$ peak in surrounding lake and marine sediments (Zheng et al., 2008; Su C and Huh C, 2002). (corresponding to 1971) and $13 \mathrm{~cm}$ depth (corresponding to1977) in CORE-1, and at $17 \mathrm{~cm}$ depth (corresponding to1971) and $15 \mathrm{~cm}$ (corresponding to 1976) in CORE-2. Although the 1976/1977 peaks

257 are not significant and are followed by higher values after that (Fig. 3 a), the contribution of the elevated 258 air release from Marcoule (France) since 1977 for these peaks could be excluded out due to the long 259 distance and hysteresis quality of marine sediment record. Since the Partial Test Ban Treaty was signed in 1963, only some atmospheric testing was undertaken by China and France (Zheng et al., 2008). The 
distance (in the south of $21^{\circ} \mathrm{S}$ ) by French atmospheric NWTs in 1960-1974 makes the only possible origin for these two peaks to be from Lop Nor site, which conducted 22 atmospheric NWTs in 19641980. The relative high fission yield tests were made in 1967-1970, 1973, and 1976 respectively (Fig. $3 \mathrm{c}$ ), which correspond well with the ${ }^{129} \mathrm{I}^{127} \mathrm{I}$ peaks in the sediment cores (Fig. 3 a) with just 2-3 years lag. The first peak in 1971 should be attributed to the first extensive tests interval during 1967-1970 with 3 years' time lag. The second peak in 1976/1976 might be the result of the combinative signal of the two high fission yield tests in 1973 (1.5 Mt) and 1976 (2.3 Mt). The 2-3 years' time discrepancy can result from the hysteresis quality leading by transportation process. The specific transportation process is singled out to discuss in section 4.2 due to the scarce reports on the specified transportation of Chinese NWTs in mainland China.

\subsubsection{Nuclear accidents}

No significantly elevated ${ }^{129} \mathrm{I}$ concentrations or ${ }^{129} \mathrm{I} /{ }^{127} \mathrm{I}$ ratios were observed around 1986 and 2011 in the two cores indicating no significant contribution from the accidents at Chernobyl and Fukushima. The Chernobyl accident in 1986 released about $1.3-6 \mathrm{~kg}{ }^{129} \mathrm{I}$ to the environment (Aldahan et al., 2007; Hou et al., 2009b). The main radioactive plume dispersed and deposited in Europe by means of the dominant east wind. Only a total deposition of 7.8-36 g ${ }^{129} \mathrm{I}$ mainly in north China is estimated according to the yield of $0.5-0.7 \%$ of the total ${ }^{131}$ I that transported to China (Fan et al., 2016). The relatively small deposition and the high ${ }^{129}$ I background from NFRPs since 1980 makes the Chernobyl accident a negligible contribution of ${ }^{129} \mathrm{I}$ in the ECS. It was estimated that Fukushima accident released about 1.2 $\mathrm{kg}{ }^{129} \mathrm{I}$ (including $0.35 \mathrm{~kg}$ direct marine discharge) to the environment (Hou et al., 2013). However, the atmospheric releases dispersed eastwards and mostly deposited in the North Pacific Ocean, and the radioactive substances discharges to the sea including ${ }^{129}$ I were mainly transported eastwards too as reported before (Tang et al., 2016), and the investigation on ${ }^{129} \mathrm{I}$ in the seawater from the ECS has also showed no detection signal of Fukushima nuclear accident even in August 2013 (Liu, et al., 2016).

\subsection{4 ${ }^{129}$ I source from nuclear fuel repressing plants by atmospheric dispersion}

In the two cores, the ${ }^{129} \mathrm{I} /{ }^{127} \mathrm{I}$ ratios rise progressively from late 1970 s and remain at a constant high level of $(54.7-75.6) \times 10^{12}$ afterwards, which is more than 2 folds higher than the lower part $((17-32) \times$ 
$10^{12}$ ) except the peak value around 1966 layer in CORE-1. This might be attributed to the releases from

290 La Hague (1966-), Sellafield (1951-) and Marcoule (1959-1997) in Europe. The atmospheric release

291 of ${ }^{129}$ I increased from late 1970s (Fig. 3 d) (Reithemier et al., 2006; Hou et al., 2009b), and kept the 292 constant high value of $20 \mathrm{~kg} / \mathrm{y}$ until 1996, then rapidly decreased to $4.6 \mathrm{~kg} / \mathrm{y}$ because of the improved 293 reprocessing technologies and the close of NFRP at Marcoule in 1997 . However, the ${ }^{129} \mathrm{I} /{ }^{127} \mathrm{I}$ ratios in 294 two sediment cores still remain the high value from the late 1990s. The re-emission of ${ }^{129}$ I in European 295 seawater discharged from the NRFPs might be responsible. The ${ }^{129} \mathrm{I} /{ }^{127} \mathrm{I}$ ratios up to $10^{-6}$ have been 296 observed in the seawater in European seas (North Sea, Baltic Sea and Norwegian Sea) and Arctic Sea 297 due to the increased marine discharges of ${ }^{129} \mathrm{I}$ at Sellafield and La Hague from $80 \mathrm{~kg} / \mathrm{y}$ in 1995 to 350 $298 \mathrm{~kg} / \mathrm{y}$ in 2000 and this level remains high (Fig. 3 d) (Reithmerier et al., 2006; Hou et al., 2009b). The 299 high level of ${ }^{129} \mathrm{I}$ with the similar ${ }^{129} \mathrm{I} /{ }^{127} \mathrm{I}$ ratio of $10^{-8}-10^{-6}$ was found in aerosols and rainwater samples 300 in the North Europe (Denmark, Germany and Sweden), confirming the re-emission of the marine 301 discharged ${ }^{129}$ I from NFRPs at Sellafield and La Hague to the atmosphere in Europe (Englund et al., 302 2010; Hou et al., 2009a). Based on the relatively constant high ${ }^{129} \mathrm{I} /{ }^{127} \mathrm{I}$ ratio in both cores from late $3031970 \mathrm{~s}$, the amount of re-emitted ${ }^{129} \mathrm{I}$ from the seawater can be estimated to be about $15 \mathrm{~kg} / \mathrm{y}$ to 304 compensate for the reduced atmospheric discharges from $20 \mathrm{~kg}$ to $4.6 \mathrm{~kg}$ after 1997.

305 Even through the relative transportation of ${ }^{129} \mathrm{I}$ by Westerlies from Europe to Asia and even America 306 has been frequently discussed (Fan et al, 2016; Zhang et al., 2018; Moran et al., 1999; Toyama et al., 307 2012), a typical process to deliver ${ }^{129}$ I to the ECS with monsoon climate will be given below. The 308 Westerlies mainly occupy the belt of $35^{\circ} \mathrm{N}-65^{\circ} \mathrm{N}$ and occur in the middle troposphere to lower 309 stratosphere (around 1500m-12000m). The ${ }^{129}$ I from NFRPs in Europe could not be directly deposited 310 in study area due to the less influence of Westerlies due to the boundary with Monsoon from the Great 311 Khingan mountain range in a southwesterly direction towards central Tibet around $32^{\circ} \mathrm{N}$ (Fig. 1) (Chen 312 et al., 2009). The East Asia Winter Monsoon should be the main driving force for the ${ }^{129}$ I moving 313 southwards that carried by the Westerlies. When the East Asia Winter Monsoon (EAWM) prevails 314 across Eurasia in Nov - May, the cold air from Mongolia and Siberia with high ${ }^{129}$ I concentration spills 315 southeastwards to the wide southeastern monsoon area of China. Higher values of ${ }^{129} \mathrm{I} /{ }^{127} \mathrm{I}$ ratios were 
measured in rainwater collected in winter and spring from Xi' an $\left(2.5 \times 10^{-8}-4 \times 10^{-8}\right)$ than that in summer and autumn (around $1 \times 10^{-8}$ ), indicating the influence of the EAWM (Jiang, 2017). The two times higher ${ }^{129} \mathrm{I}$ deposition in spring in Tokyo compared to that in autumn is due to the spring prevailing western wind under the EAWM (Toyama et al., 2012). There is also agreement between high levels of ${ }^{129}$ I level and the enhanced EAWM in Taal Lake $\left(14^{\circ} \mathrm{N}\right)$ sediment core from Philippines (Zhang et al., 2018). The combination action of Westerlies with EAWM is the main force for the atmospheric ${ }^{129} \mathrm{I}$ originated from European NFRPs to be delivered to the sampling sites in ECS and the relative drainage basin of input rivers. The transfer process of ${ }^{129} \mathrm{I}$ from drainage basin to the sediment will be discussed in 4.2.2.

\subsubsection{Other possible sources of ${ }^{129} I$}

The influence of nearby operating nuclear power plants and other small reprocessing plants is expected to be negligible here. The ${ }^{129}$ I produced in nuclear fuel as a fission product is usually well sealed inside the fuel elements, and only a small part of ${ }^{129} \mathrm{I}$ is released to the environment by reprocessing of the spent fuel or accidents of the reactor. The measurement of ${ }^{129} \mathrm{I}$ in sea water from the vicinity area of a Chinese NPPs $(<7 \mathrm{~km})$ showed no difference in the ${ }^{129} \mathrm{I} /{ }^{127} \mathrm{I}$ atomic ratios $\left(8.29 \times 10^{-}\right.$ ${ }^{11}-9.45 \times 10^{-10}$ ) compared to that in the background area (He et al., 2011). The investigation on the distribution of ${ }^{129} \mathrm{I}$ in surface soil showed no elevated ${ }^{129} \mathrm{I}$ level nearby the NFRPs in China indicating no obvious contribution (Fan, 2013). There is no extra contribution of ${ }^{129}$ I from the nearest Tokai NFRP which operating from $1977-2005$ with about $1 \mathrm{~kg}{ }^{129} \mathrm{I}$ released to the environment in total, as demonstrated by the constant low ${ }^{129} \mathrm{I}$ level in the precipitation in Ishigaki-shima $\left(24^{\circ} \mathrm{N}, 124^{\circ} \mathrm{E}\right)$ (Toyama et al., 2013) and in surface seawater around Japan (Suzuki et al., 2010) and ECS (Liu et al., 2016) until 2013 (Toyama et al., 2012). The influence from Chinese NFRPs, Guangyuan and Jiuquan reprocessing plants, operating from 1975-1991 and 1968-1984, can be excluded too. Although, the reported ${ }^{129} \mathrm{I}^{127} \mathrm{I}$ ratios in surface soil near Jiuquan is up to $3.8 \times 10^{-8}$, near Guangyuan is $5 \times 10^{-9}$, the ${ }^{129} \mathrm{I} /{ }^{127} \mathrm{I}$ ratios in surrounding area and most surface soil in China were $10^{-10}-10^{-9}$, indicating only some local influence (Fan, 2013). 


\subsection{The record of Lop Nor NWTs in the sediment core and its transportation pathway}

The releases of the high yield tests in 1967-1970 and 1973-1976 at Lop Nor were well recorded in the sediment cores in the ECS as showed by the ${ }^{129} \mathrm{I} /{ }^{127} \mathrm{I}$ peaks in 1971 and $1976 / 7$. The transportation of released ${ }^{129} \mathrm{I}$ might be carried by directly atmospheric dispersion and deposition and the following riverine input. The transportation processes are firstly discussed below.

\subsubsection{Atmospheric transport from Lop Nor}

A great amount of radioactive materials including ${ }^{129}$ I from atmospheric NWTs at Lop Nor was injected to the troposphere at different height and even directly to the stratosphere with high yield due to the main air-drop explosion (except the 28 Dec 1966 by tower explosion) with average height over $500 \mathrm{~m}$ above the ground (UNSCEAR 2000), which was then dispersed to a large area due to the temporal atmospheric circulation conditions.

The radioactive substances released to less than $1000 \mathrm{~m}$ height mainly dispersed to the Taklimakan Desert and the downwind area with locally prevailing strong ENE winds from March to November, and less frequent WSW wind during winter showed in Fig. 4 a (Yang et al., 2015), and it would be impossible to reach to the sampling site in the ECS with over $5000 \mathrm{~km}$ southeast. The forward trajectories by the HYSPLIT model of air mass below $1000 \mathrm{~m}$ after most tests at Lop Nor moved southwestwards too (Fig. 4 b). The radioactive substances released to the height of 1000-6000 m, the major part of troposphere with strong westerly wind dominates throughout the year above Lop Nor $\left(41^{\circ}\right.$ $30^{\prime} \mathrm{N}, 88^{\circ} 30^{\prime} \mathrm{E}$ ) mainly moved eastwards to the Pacific as records in Tokyo (Kuroda et al., 1965) and simulated trajectories (Fig. 4 c), with only the plume at $4000 \mathrm{~m}$ after the test of Sep. 29, 1969 possibly reaching South China, and not likely reaching the sampling sites (Fig. 4 d). The radioactive substances released to the height above $6000 \mathrm{~m}$, where the Westerlies flows more quickly and straightly in the top of troposphere and bottom of stratosphere (6000-11000 m), moved straightforward to east but scarcely to the south China and the ECS as showed in the forward trajectory analysis by HYSPLIT model (Fig. 4 e and f) and the stratospheric strontium signal detected in north Japan (Kuroda et al., 1965). It can be therefore concluded that the ${ }^{129}$ I record in the sediment cores in the ECS could not be a result of directly atmospheric transport and deposition to the ECS from Lop Nor. 

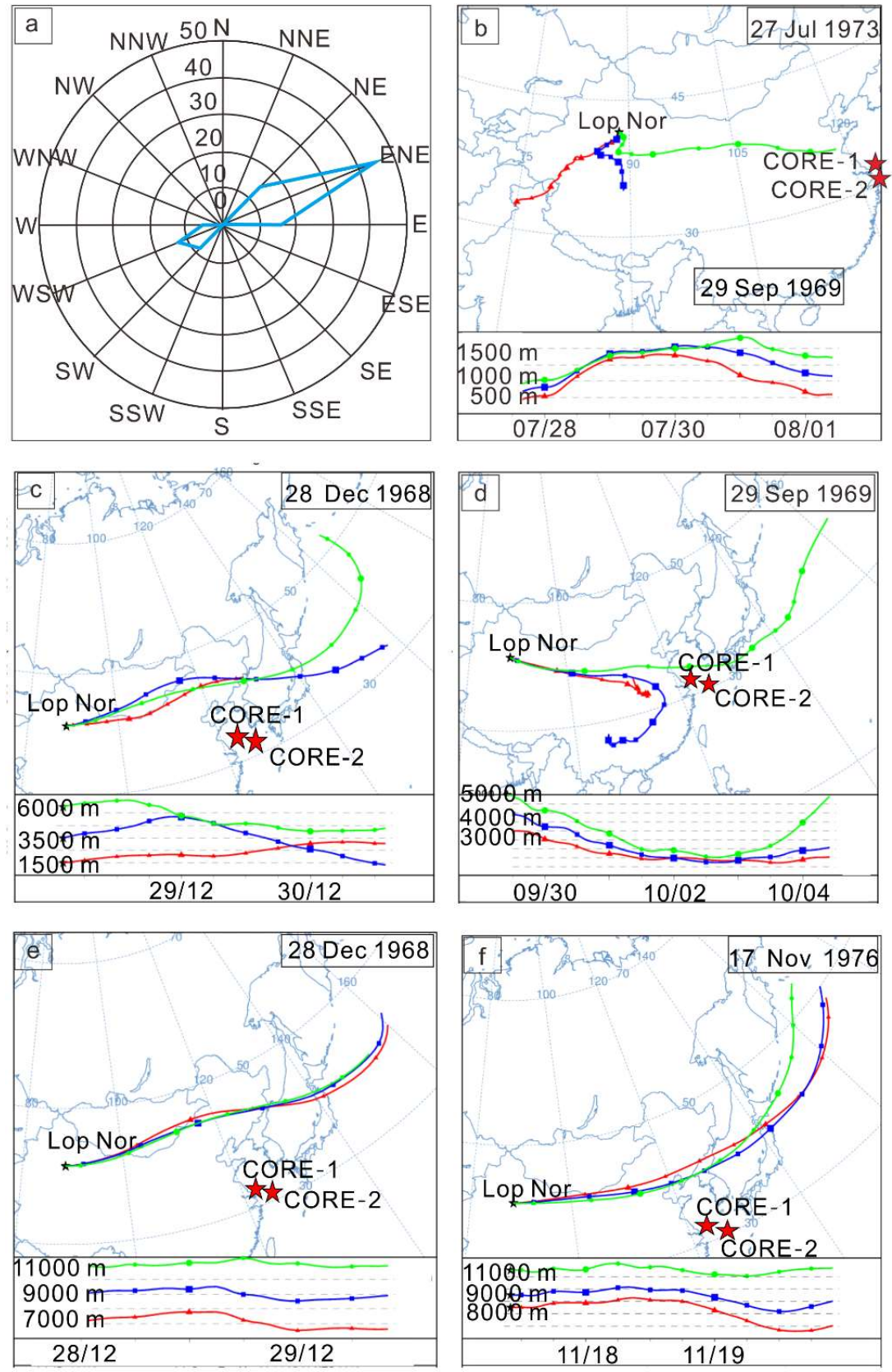

Fig. 4. The wind rose of maximum wind speed in Ruoqiang County from 1980-2012 (a) (Yang et al., 2015). ENE winds lead most time with less frequent WSW winds; Forward trajectories in 500-1500 m after tests at Lop Nor dispersed to the Taklimakan Desert (b); Forward trajectories of air mass in 1500-6000 m after tests at Lop Nor mainly moved eastwards (c and d); Former trajectories of air mass above $6000 \mathrm{~m}$ after tests at Lop Nor moved eastwards (e and f).

\subsubsection{Riverine transport of the radioactive substances from Lop Nor}

The sampling sites are located in a convergence zone of ocean current (TWC) and terrestrial input through CDW and YSCC, of which the Changjiang River, Yellow River and Liao River might be 
times larger area of these drainage basins (Changjiang River: $1800000 \mathrm{~km}^{2}$; Yellow River: 750000 $\mathrm{km}^{2}$; Liao River: $\left.219000 \mathrm{~km}^{2}\right)$ than that of the ECS (353 $\left.000 \mathrm{~km}^{2}\right)(\mathrm{Su}$ C and Huh C, 2002), the leaching of ${ }^{129}$ I deposited on the catchment from Lop Nor NWTs and European NFRPs through rain water washout could be an important pathway. The short residence time and shallow penetration depth of surface $10 \mathrm{~cm}$ in drainage basin soil (Hou et al., 2009b) promotes ${ }^{129} \mathrm{I}$ prior to leach out than the stable iodine and produce a relative higher ${ }^{129} \mathrm{I} /{ }^{127} \mathrm{I}$ ratio in river water than that in soil.

\section{(1) Changjiang River input}

Several southeastwards plumes after tests at Lop Nor (such as that at $1500 \mathrm{~m}$ after the test at Jul. 27 1973 in Fig. 4 b, plume at $3000 \mathrm{~m}$ and $4000 \mathrm{~m}$ after the test at Sep. 291969 in Fig. 4 d could bring the radioactive substances to the east edge of Tibet Plateau, where the two most important branches of Changjiang River, Jinsha River and Yalong River, located that covering over 30\% of the total Changjiang Basin area. Although no ${ }^{129} \mathrm{I}$ data in water sample or soil sample from Jinsha River and Yalong River is available yet, the soluble and exchangeable iodine could be leached out due to the widely developed water erosion and anaerobic soil condition during plum rain season controlled by the monsoon climate (Hou et al., 2009b), and then transported to the ECS. The higher atomic ratios of ${ }^{129} \mathrm{I} /{ }^{127} \mathrm{I}$ in water sample $\left(1000 \times 10^{-12}\right)$ from Middle Changjiang River in Chongqing than that in the surface soil (south of $30^{\circ} \mathrm{N} \leq 100 \times 10^{-12}$ ) (Fan, 2013; Chen, communication), and a decreasing trend of ${ }^{129} \mathrm{I}$ level in surface seawater from the estuary area to southeast along CDW (Liu et al. 2016) was both observed, indicating that ${ }^{129} \mathrm{I}$ can be leached out from the Changjiang Basin and therefore be an input source to the ECS. Then the ${ }^{129} \mathrm{I}$ can be preserved in study sediment as the death of marine organisms that concentrate iodine from seawater (Price et al., 1973) besides the directly atmospheric and terrestrial material bounded ${ }^{129} \mathrm{I}$.

\section{(2) Yellow River and Liao River transportation}

Most of radioactive substances released from Lop Nor were transported eastward and northeastward and deposited in North China, where the catchment of the Yellow River and Liao River are located. ${ }^{129} \mathrm{I}$ deposited on soil tends to be easily leached out because of the dry weather, low vegetation coverage 
and concentrated precipitation in the upstream area of Yellow River (Zhang et al., 2013). A higher ${ }^{129} \mathrm{I} /{ }^{127} \mathrm{I}$ ratio of $2000 \times 10^{-12}$ was measured in the Yellow River water collected in Ningxia Provence compared to that in the surface soil of surrounding area $\left((100-1000) \times 10^{-12}\right)($ Fan, 2013; Chen, communication), indicating leaching out of ${ }^{129} \mathrm{I}$ from soil. A distinct ${ }^{129} \mathrm{I} /{ }^{127} \mathrm{I}$ ratio peak in 1970 s in the sediment core from Jiaozhou Bay and high level ${ }^{129} \mathrm{I}$ in the coastal seawater in the Bohai Sea clearly recorded the Yellow River and Liao River input of ${ }^{129}$ I from Lop Nor (Fan et al., 2016; Liu, 2017). The water enriched ${ }^{129}$ I can then move further to the sampling sites through the YSCC.

The total amount of the annual ${ }^{129} \mathrm{I}$ input in 2013 is estimated to be $6.6 \times 10^{11}$ atoms $/ \mathrm{m}^{2} / \mathrm{y}$ by combining the three river inputs(Changjiang River: $1.5 \times 10^{11}$ atoms $/ \mathrm{m}^{2} / \mathrm{y}$; Yellow River: $2.5 \times 10^{11}$ atoms $/ \mathrm{m}^{2} / \mathrm{y}$; Liao River: $2.6 \times 10^{11}$ atoms $/ \mathrm{m}^{2} / \mathrm{y}$ for), which exceeds the direct atmospheric deposition $\left(0.36 \times 10^{11}-4.3 \times 10^{11}\right.$ atoms $\left./ \mathrm{m}^{2} / \mathrm{y}\right)$ as reported in Tokyo, that located in northeast $1400 \mathrm{~km}$ of study area (Toyama et al., 2012) (Supplementary Information 3), indicating riverine input is the primary source and pathway of ${ }^{129}$ I derived from Lop Nor and the NFRPs in the sediment from ECS. The overall transit time of the whole processes is estimated to be $0.5-3$ years which matches well with the 1-3 years lag in study sediment records (Supplementary Information 4).

\section{Conclusion}

Based on the results of ${ }^{129} \mathrm{I}$ in two sediment cores collected in the ECS, it can be concluded: (1) The ECS was significantly influenced by human nuclear activities, and the ${ }^{129} \mathrm{I} /{ }^{127} \mathrm{I}$ ratios are in the level of $10^{-11}$; (2) The radioactive substances in the sediment in the ECS mainly originated from the nuclear weapon tests at Pacific Proving Grounds before 1960, global NWTs fallout peak around 1963, Chinese nuclear weapon tests in 1967-1980, and the two European NFRPs from late 1970s; (3) The transportation through ocean currents is of great importance in the dispersing of radioactive substances from the low-latitude tests sites at PPG to middle latitude; (4) The radioactive substance released from the NWTs at Lop Nor and deposited in the downwind drainage basins contributed to the inventory in the sediment in the ECS through rainwater leaching of soil, riverine input and sea current transferring; (5) The constantly high level of ${ }^{129}$ I in 1979-2010 in the sediment cores mainly resulted from the direct 
430 atmospheric releases in 1979-1997 and the re-emission of the marine discharges in 1997-2010 from the

431 European NFRPs; (6) The combined action of Westerlies with East Asian Winter Monsoon is the mainly

432 driving force in the airborne radionuclides disperse from high latitude in West Europe to low latitude 433 in East Asia.

\section{Acknowledgements}

435 This work was supported by the Ministry of Science and Technology of China [No. 2015FY110800], 436 Natural Science Foundation of China [No.11605207], and the State Key Laboratory of Loess and

437 Quaternary Geology. The sediment cores were collected and prepared by Dr. Jinlong Wang and 438 colleagues in East Normal University. AMS measurement of ${ }^{129}$ I was performed by Dr. Qi Liu in the

439 Xi'an AMS Center. X. Zhao thank Dr. Ning Chen from Institute of Earth Environment for providing 440 some unpublished data and Dr. Jixin Qiao from Center for Nuclear Technologies, Technical University 441 of Denmark for her constructive suggestion and comments on manuscript.

\section{Reference}

443 Aldahan A, Englund E, Possnert G, et al., 2007. Iodine-129 enrichment in sediment of the Baltic Sea. 444 Applied Geochemistry. 22, 637-647. https://doi.org/10.1016/j.apgeochem.2006.12.009

445 Bautista A, Matsuzaki H, Siringan F, 2016. Historical record of nuclear activities from ${ }^{129} \mathrm{I}$ in corals 446 from the northern hemisphere (Philippines). Journal of Environmental Radioactivity. 164: 174-181. 447 https://doi.org/10.1016/j.jenvrad.2016.07.022

448 Chang C, Burr G S, Jull A J, et al., 2016. Reconstructing surface ocean circulation with ${ }^{129}$ I time series 449 records from corals. Journal of Environmental Radioactivity. 165, 144-150. 450 https://doi.org/10.1016/j.jenvrad.2016.09.016

451 Chang C, 2016. Iodine-129 as an Oceanic Tracer. The University of Arizona, Tucson, pp. 6471.

452 Chen F, Chen, Huang W, 2009. A discussion on the Westerly-dominated climate model in mid-latitude 453 Asia during the modern interglacial period. Earth Science Frontiers. 16, 023-032. 454 https://doi.org/10.3321/j.issn:1005-2321.2009.06.003

455 Chen N, Personal Communication. The ${ }^{129}$ I level in river water samples from China.

456 Englund E, Aldahan A, Hou X, et al., 2010. Iodine $\left({ }^{129} \mathrm{I}\right.$ and $\left.{ }^{127} \mathrm{I}\right)$ in aerosols from northern Europe. 457 Nuclear Instruments \& Methods in Physics Research. 268, 1139-1141. 458 https://doi.org/10.1016/j.nimb.2009.10.118 
459 Englund E, Aldahan A, Possnert G, 2008. Tracing anthropogenic nuclear activity with ${ }^{129} \mathrm{I}$ in lake

460 sediment. Journal of Environmental Radioactivity. 99, 219-229.

461 https://dx.doi.org/10.1016/j.nimb.2009.10.109

462 Fan Y, 2013. Spatial distribution of ${ }^{129} \mathrm{I}$ in Chinese surface soil and preliminary study on the ${ }^{129} \mathrm{I}$

463 chronology. Chinese Academy of Sciences (Institute of Earth Environment Science), Beijing (in

464 Chinese), pp. 40-46.

465 Fan Y, Hou X, Zhou W, et al., 2016. ${ }^{129}$ I record of nuclear activities in marine sediment core from

466 Jiaozhou Bay in China. Journal of Environmental Radioactivity. 154, 15-24.

467 https://dx.doi.org/10.1016/j.jenvrad.2016.01.008

468 Gallagher D, McGee E J, Mitchell P I, et al., 2005. Retrospective Search for Evidence of the 1957

469 Windscale Fire in NE Ireland Using ${ }^{129} \mathrm{I}$ and Other Long-Lived Nuclides. Environmental Science \&

470 Technology. 39, 2927-35. https://doi.org/10.1021/es0490491

471 Handl J, Pfau A, Huth F W, 1990. Measurements of ${ }^{129} \mathrm{I}$ in human and bovine thyroids in Europe--

472 transfer of 129I into the food chain. Health Physics. 58, 609-618. https://doi.org/10.1097/00004032-

$473 \quad 199005000-00006$

474 He C, Hou X, Zhao Y, et al., 2011. ${ }^{129}$ I level in seawater near a nuclear power plant determined by 475 accelerator mass spectrometer. Nuclear Instruments \& Methods in Physics Research. 632, 152-156. 476 https://doi.org/10.1016/j.nima.2010.12.182

477 Hou X, Yan X, 1998. Study on the concentration and seasonal variation of inorganic elements in 35 478 species of marine algae. Science of the Total Environment. 222, 141-156. 479 https://doi.org/10.1016/S0048-9697(98)00299-X

480 Hou X, Aldahan A, Nielsen S P, et al., 2009a. Time series of ${ }^{129} \mathrm{I}$ and ${ }^{127} \mathrm{I}$ speciation in precipitation 481 from Denmark. Environmental Science \& Technology. 43, 6522-6528. 482 https://doi.org/10.1021/es9012678

483 Hou X, Hansen V, Aldahan A, et al., 2009b. A review on speciation of iodine-129 in the environmental 484 and biological samples. Analytica Chimica Acta. 632, 181-196. 485 https://doi.org/10.1016/j.aca.2008.11.013

486 Hou X, Zhou W, Chen N, et al., 2010. Determination of ultralow level ${ }^{129} \mathrm{I} /{ }^{127} \mathrm{I}$ in natural samples by 487 separation of microgram carrier free Iodine and Accelerator Mass Spectrometry detection. Analytical 488 Chemistry. 82, 7713-7721. https://doi.org/10.1021/ac101558k

489 Hou X, Povinec P P, Zhang L, et al., 2013. Iodine-129 in seawater offshore Fukushima: distribution, 490 inorganic speciation, sources, and budget. Environmental Science \& Technology. 47, 3091-3098. 491 https://doi.org/10.1021/es304460k

492 Hou X, Zhang D, 2018. Determination of ${ }^{129} \mathrm{I}$ in environmental solid samples using pyrolysis separation 493 and accelerator mass spectrometry measurement. Journal of Radioanalytical \& Nuclear Chemistry (11): 494 1-13. https://doi.org/10.1007/s10967-018-5859-4

495 Jiang X, 2017. A study on the level and variation of ${ }^{129} \mathrm{I}$ in precipitation in $\mathrm{Xi}$ ' an region and its 496 application as environmental tracer. Chinese Academy of Sciences (Institute of Earth Environment 497 Science), Beijing (in Chinese), pp. 43-46.

498 Kuroda P K, Miyake Y, Nemoto J, 1965. Strontium Isotopes: Global Circulation after the Chinese 499 Nuclear Explosion of 14 May 1965. Science. 150, 1289-1290. 500 http://doi.org/10.1126/science.150.3701.1289 
501 Li G, Han X, Yue S, et al., 2006. Monthly variations of water masses in the East China Seas. Continental 502 Shelf Research. 26, 1954-1970. https://doi.org/10.1016/j.csr.2006.06.008

503 Liu D, Hou X, Du J, et al., 2016. ${ }^{129}$ I and its species in the East China Sea: level, distribution, sources 504 and tracing water masses exchange and movement. Scientific Reports. 6, 36611-36619. 505 https://doi.org/10.1038/srep36611

506 Liu D, 2017. Tracing application of ${ }^{129} \mathrm{I}$ in the marine environment. Chinese Academy of Sciences 507 (Institute of Earth Environment Science), Beijing (in Chinese), pp. 57-63.

508 Liu J, Xu K, Li A et al., 2007. Flux and fate of Yangtze River sediment delivered to the East China Sea. 509 Geomorphology. 85, 208-224. https://doi.org/10.1016/j.geomorph.2006.03.023

510 López-Gutiérrez J M, Santos F J, GarcíA-León M, et al., 2004. Levels and temporal variability of ${ }^{129}$ I 511 concentrations and ${ }^{129} \mathrm{I} /{ }^{127} \mathrm{I}$ isotopic ratios in atmospheric samples from southern Spain. Nuclear Inst \& 512 Methods in Physics Research B. 223-224, 495-500. https://doi.org/10.1016/j.nimb.2004.04.093

513 Moran J E, Schink D R, Oktay S, et al., 1999. Atmospheric dispersal of ${ }^{129}$ I from nuclear fuel 514 reprocessing facilities. Environmental Science \& Technology. 33, 2536-2542. 515 https://doi.org/10.1021/es9900050

516 Moran J E, Fehn U, Teng R TD, 1998. Variations in ${ }^{129} \mathrm{I} /{ }^{127} \mathrm{I}$ ratios in recent marine sediments: 517 evidence for a fossil organic component. Chemical Geology. 152, 193-203. 518 https://doi.org/10.1016/S0009-2541(98)00106-5

519 Oktay S D, Santschi P H, Moran J E, et al., 2000. The 129-iodine bomb pulse recorded in Mississippi 520 River Delta sediments: results from isotopes of $\mathrm{I}, \mathrm{Pu}, \mathrm{Cs}, \mathrm{Pb}$, and $\mathrm{C}$. Geochimica Et Cosmochimica 521 Acta. 64, 989-996. https://doi.org/10.1016/S0016-7037(99)00364-6

522 Price N B, Calvert S E. 1973. The geochemistry of iodine in oxidised and reduced recent marine 523 sediments. Geochimica Et Cosmochimica Acta. 37, 2149-2158. https://doi.org/10.1016/0016$524 \quad$ 7037(73)90013-6

525 Reithmeier H, Lazarev V, Rühm W, et al., 2006. Estimate of European 129I Releases Supported by ${ }^{129}$ I 526 Analysis in an Alpine Ice Core. Environmental Science \& Technology. 40, 5891-5896. 527 https://doi.org/10.1021/es0605725

528 Santos F J, López-Gutiérrez J M, García-León M, et al., 2007. ${ }^{129}$ I record in a sediment core from Tinto 529 River (Spain). Nuclear Instruments \& Methods in Physics Research. 259, 503-507. 530 https://doi.org/10.1016/j.nimb.2007.01.192

531 Sasaki H, Siswanto E, Kou N, et al., 2008. Mapping the low salinity Changjiang Diluted Water using 532 satellite - retrieved colored dissolved organic matter (CDOM) in the East China Sea during high river 533 flow season. Geophysical Research Letters. 35, 121-134. https://doi.org/10.1029/2007GL032637

534 Stan-Sion C, Enachescu M, Petre A R, 2015. AMS analyses of I-129 from the Fukushima Daiichi 535 nuclear accident in the Pacific Ocean waters of the Coast La Jolla--San Diego, USA. Environmental 536 Science Processes \& Impacts. 17, 932-938. https://doi.org/10.1039/C5EM00124B

$537 \mathrm{Su} \mathrm{C}$ and Huh C, 2002. ${ }^{210} \mathrm{~Pb},{ }^{137} \mathrm{Cs}$ and ${ }^{239,240} \mathrm{Pu}$ in East China Sea sediments: sources, pathways and 538 budgets of sediments and radionuclides. Marine Geology. 183, 163-178. https://doi.org/10.1016/S0025$539 \quad \underline{3227(02) 00165-2}$

540 Suzuki T, Minakawa M, Amano H, et al., 2010. The vertical profiles of iodine-129 in the Pacific Ocean 541 and the Japan Sea before the routine operation of a new nuclear fuel reprocessing plant. Nuclear 
542 Instruments \& Methods in Physics Research. 268, 1229-1231.

543 https://doi.org/10.1016/j.nimb.2009.10.140

544 Tang M, Tsuang B J, Kuo P H, 2016. Dose estimation for nuclear power plant 4 accident in Taiwan at

545 Fukushima nuclear meltdown emission level. Journal of Environmental Radioactivity. 155-156, 71-83.

546 https://dx.doi.org/10.1016/j.jenvrad.2016.01.022

547 Toyama C, Muramatsu Y, Igarashi Y, et al., 2013. Atmospheric fallout of ${ }^{129} \mathrm{I}$ in Japan before the

548 Fukushima accident: regional and global contributions (1963-2005). Environmental Science \&

549 Technology. 47, 8383-8390. https://doi.org/10.1021/es401596z

550 Toyama C, Muramatsu Y, Uchida Y, et al., 2012. Variations of ${ }^{129} \mathrm{I}$ in the atmospheric fallout of Tokyo, 551 Japan: 1963-2003. Journal of Environmental Radioactivity. 113, 116-122. 552 https://doi.org/10.1016/j.jenvrad.2012.04.014

553 UNSCEAR, 2000. Sources, Effects and Risk of Ionizing Radiation. UNSCEAR 2000 Report to the 554 General Assembly, Annex C: Exposures from Man-made Sources of Radiation, New York, pp. 195555 204. https://www.unscear.org/docs/publications/2000/UNSCEAR 2000 Annex-C-CORR.pdf

556 Wang J, Baskaran M, Hou X, et al., 2017. Historical changes in ${ }^{239} \mathrm{Pu}$ and ${ }^{240} \mathrm{Pu}$ sources in sedimentary 557 records in the East China Sea: Implications for provenance and transportation. Earth \& Planetary 558 Science Letters. 466, 32-42. https://doi.org/10.1016/j.eps1.2017.03.005

559 Wei Q, Yu Z, Ran X, et al., 2011. Characteristics of the Western Coastal Current of the Yellow Sea and 560 its impacts on material transportation. Advances in Earth Science. 26, 145-156. 561 https://www.adearth.ac.cn/CN/10.11867/j.issn.1001-8166.2011.02.0145

562 Wu J, Zheng J, Dai M, et al., 2014. Isotopic composition and distribution of plutonium in northern 563 South China Sea sediments revealed continuous release and transport of $\mathrm{Pu}$ from the Marshall Islands. 564 Environmental Science \& Technology. 48, 3136-3144. https://doi.org/10.1021/es405363q

565 Yang Y, Wang R, Liu J et al., 2015. Regional dust activity history during the past 45 ka reflected by 566 sensitive grain-size components in Lop Nur, Xinjiang. Earth Science Frontiers. 22, 247-258. 567 https://doi.org/10.13745/j.esf.2015.05.021

568 Zhang L, Hou X, Li H, et al., 2018. A 60-year record of ${ }^{129} \mathrm{I}$ in Taal Lake sediments (Philippines): 569 Influence of human nuclear activities at low latitude regions. Chemosphere. 193, 1149-1156. 570 https://doi.org/10.1016/j.chemosphere.2017.11.134

571 Zhang L, Wang L, Cai W, et al, 2013. Impact of human activities on organic carbon transport in the 572 Yellow River. Biogeosciences. 10, 2513-2524. https://doi.org/10.5194/bg-10-2513-2013

573 Zheng J, Wu F, Yamada M, et al., 2008. Global fallout Pu recorded in lacustrine sediments in Lake 574 Hongfeng, SW China. Environmental Pollution. 152, 314-321. 575 https://doi.org/10.1016/j.envpol.2007.06.027 


\section{Figures caption}

Fig. 1. Sampling site of two sediment cores with possible sources, the major sea currents in the East China Sea and the dominant wind direction in China (Wang et al. 2017, Chen et al., 2009). NA, Nuclear Accident; NWT, Nuclear Weapon Test; NFRPs, Nuclear Fuel Reprocessing Plants; EASM, East Asian summer monsoon; EAWM, East Asian winter monsoon; NEC, North Equatorial Current; KC, Kuroshio Current; YSCC, Yellow Sea Coastal Current; YSWC, Yellow Sea Warm Current; CDW, Changjiang Dilute Water. TWC, Taiwan Warm Current; Boundry stands for the dividing line of monsoon region and westerly area. Sampling sites mainly receive fresh water from Yangtze River, Yellow River and Liao River through CDW and YSCC, and sea water from TWC, also is controlled by East Asian Monsoon.

Fig. 2. Depth profiles of ${ }^{127} \mathrm{I}$ and ${ }^{129} \mathrm{I}$ concentrations and in sediment CORE-1and CORE-2 from the ECS (a). Depth profiles of ${ }^{129} \mathrm{I} /{ }^{127} \mathrm{I}$ atomic ratios within time in CORE-1 and CORE2 collected in ECS (b). More drastically decreased ${ }^{127} \mathrm{I}$ along depth occurs in CORE-1. There is a less positive correlation between ${ }^{129} \mathrm{I}$ and ${ }^{127} \mathrm{I}$ concentrations in CORE-2 than CORE-1. Two synchronous peaks show in two cores around1972 and 1976/1977, and a separate peak in 1966 found in CORE-1 and a distinct small high value around 1959 in CORE-2.

Fig. 3. Comparison of measured ${ }^{129} \mathrm{I} /{ }^{127} \mathrm{I}$ ratios in the sediment cores from ECS (a) with that from Jiaozhou Bay sediment (b) (Fan et al., 2016), NWT fission yield (c) (UNSCEAR 2000), marine discharges and air discharges of ${ }^{129}$ I from NFRPs (d) (Hou et al., 2009b). The first 1959 peak in CORE-2 and Jiaozhou Bay corresponds to the NWTs around 1958; The second peak equals to the NWTs in 1961-1962; The next two peaks relate to two periods of Chinses NWTs; The high ${ }^{129} \mathrm{I} /{ }^{127} \mathrm{I}$ ratios since late 1970 s correspond to NFRPs release.

Fig. 4. The wind rose of maximum wind speed in Ruoqiang County from 1980-2012 (a) (Yang et al., 2015). ENE winds lead most time with less frequent WSW winds; Forward trajectories in 500-1500 m after tests at Lop Nor dispersed to the Taklimakan Desert (b); Forward trajectories of air mass in 1500-6000 m after tests at Lop Nor mainly moved eastwards (c and d); Former trajectories of air mass above $6000 \mathrm{~m}$ after tests at Lop Nor moved eastwards (e and f).

7

(1)

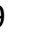

(1)

2


$616 \quad$ Fig-1

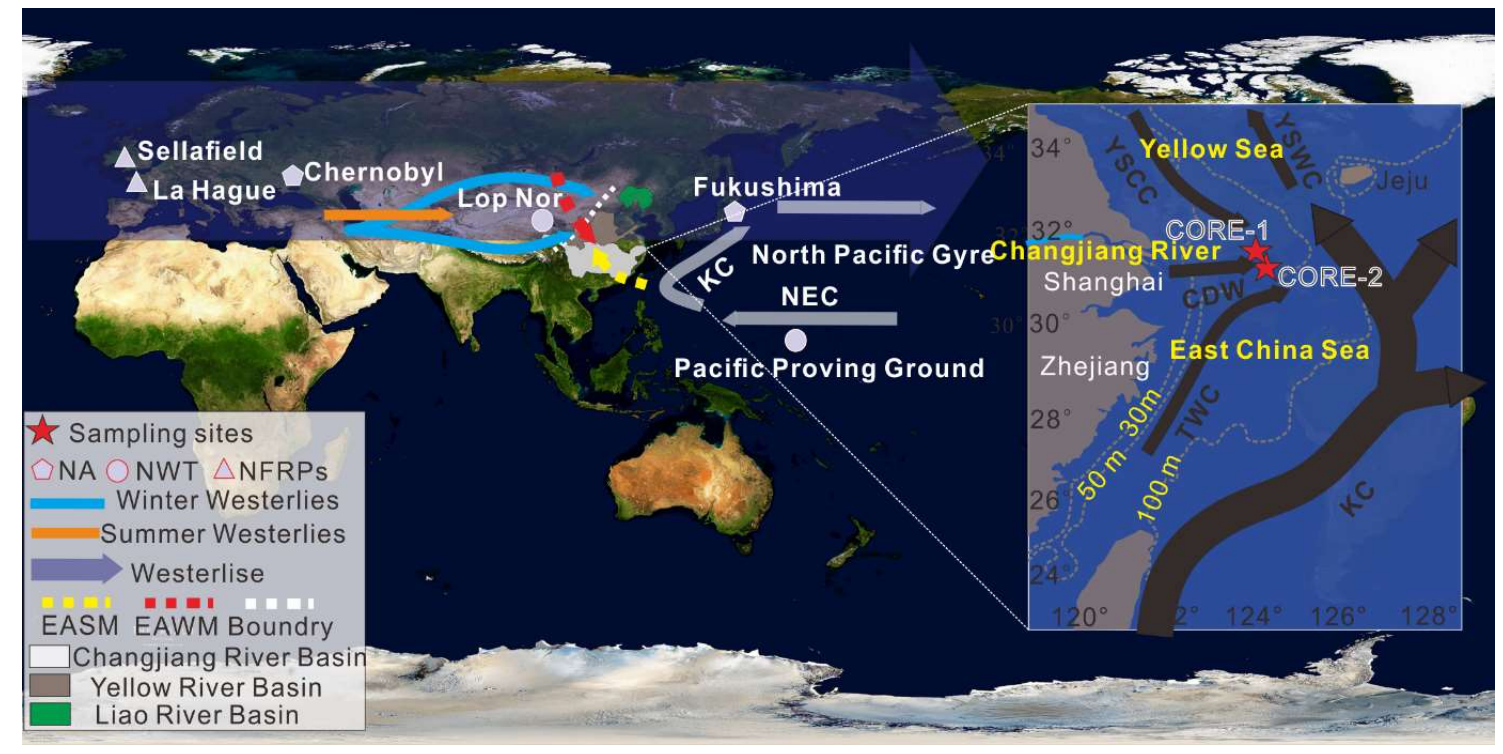




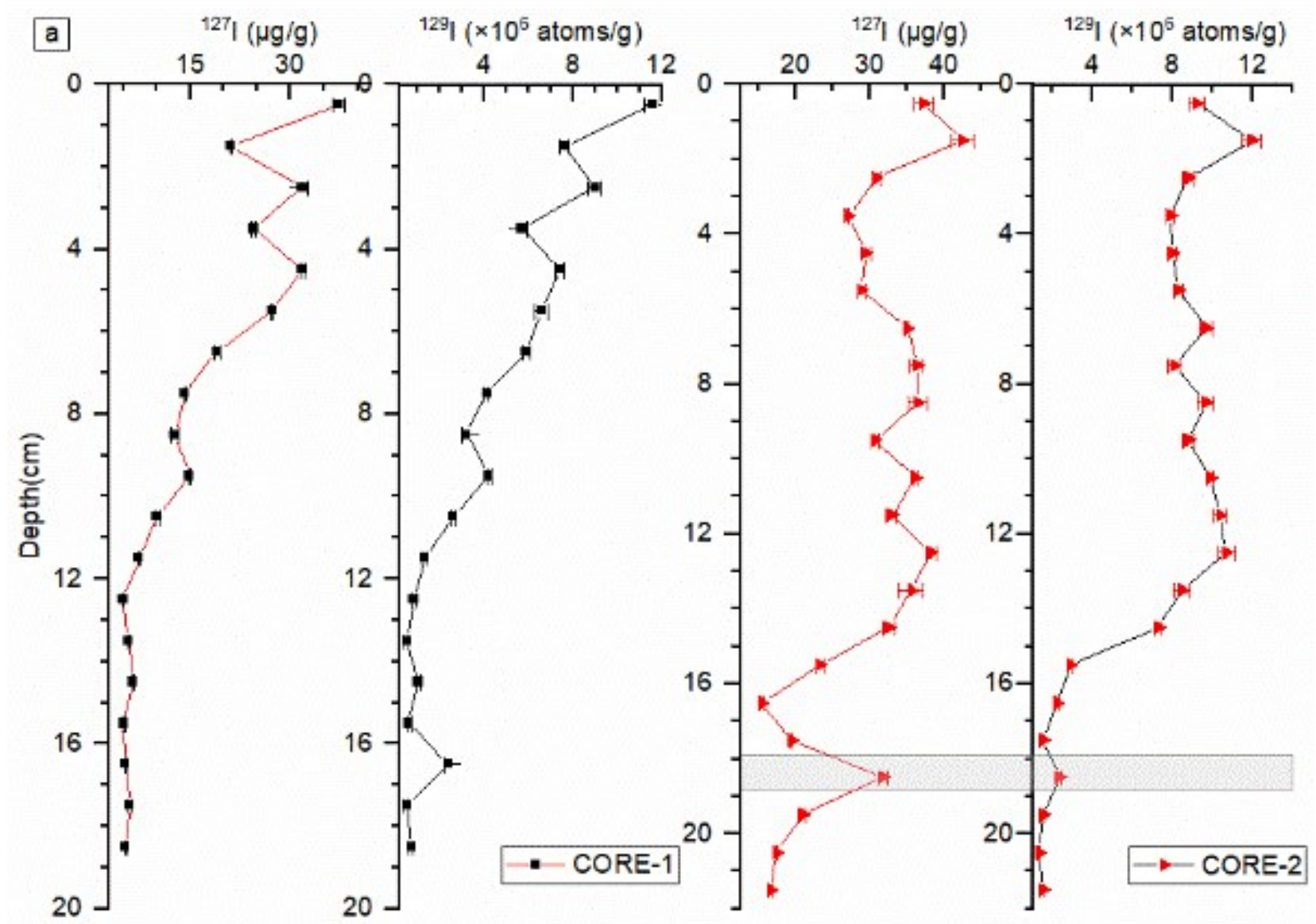




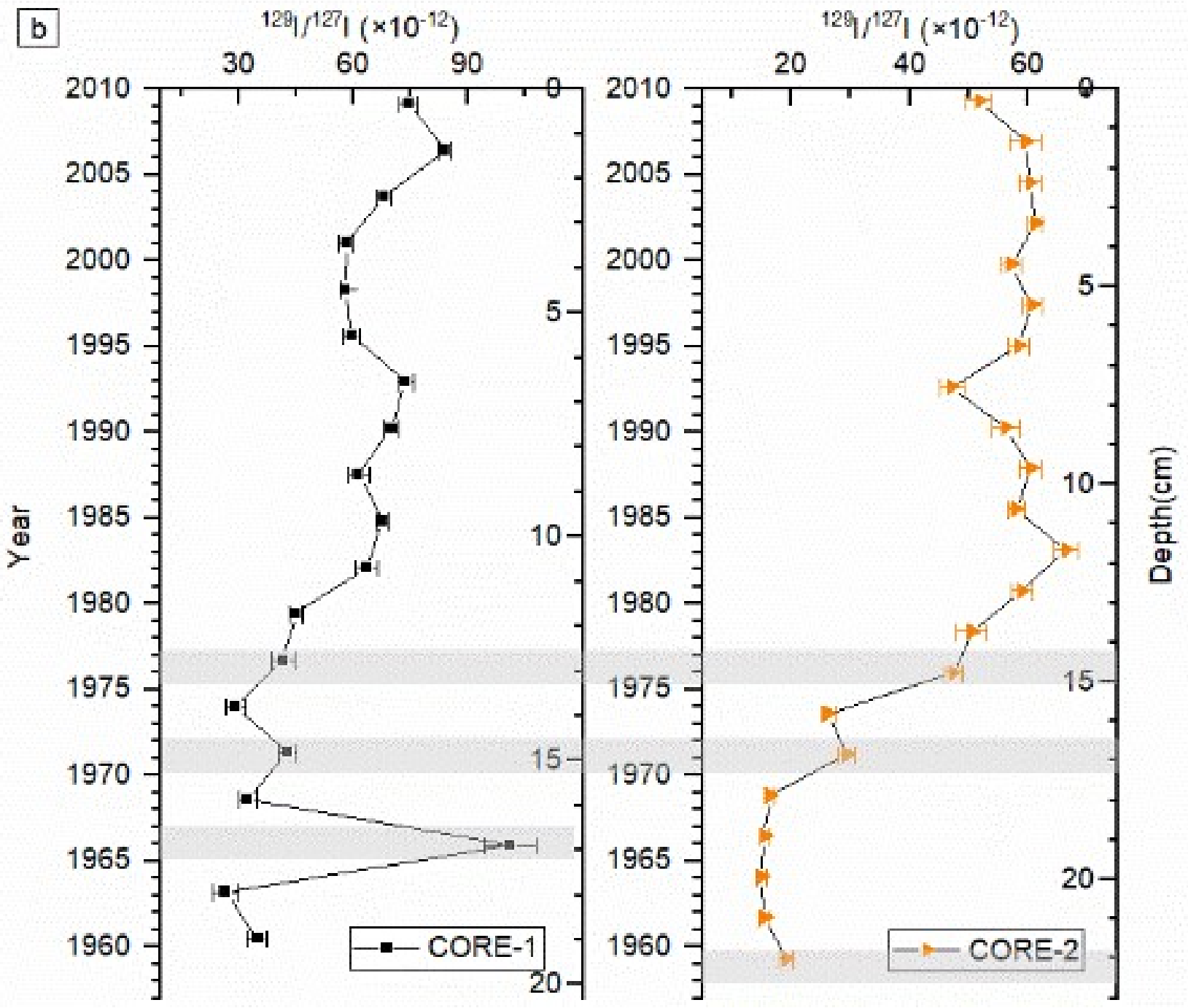


621 Fig-3

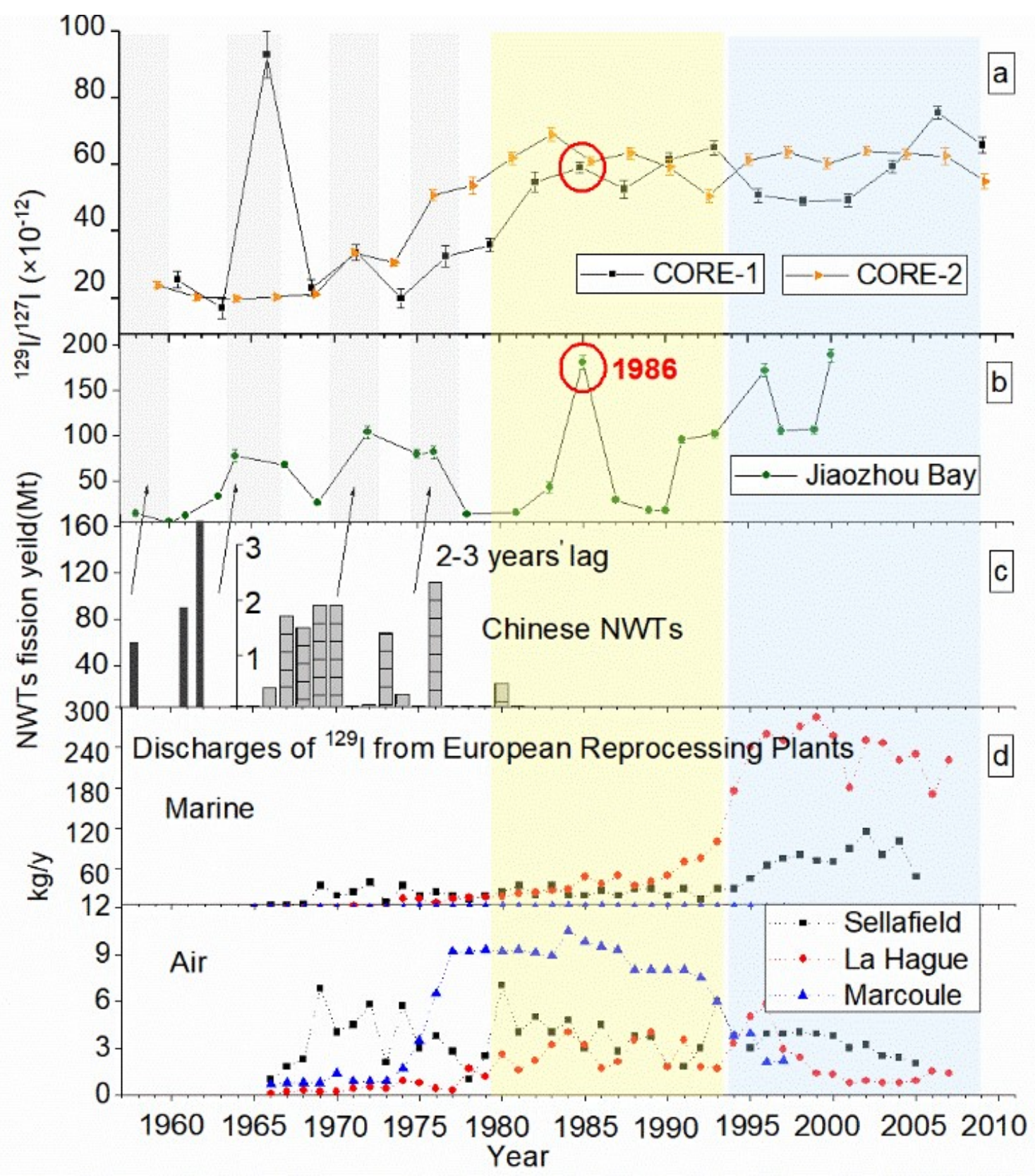


623 Fig-4
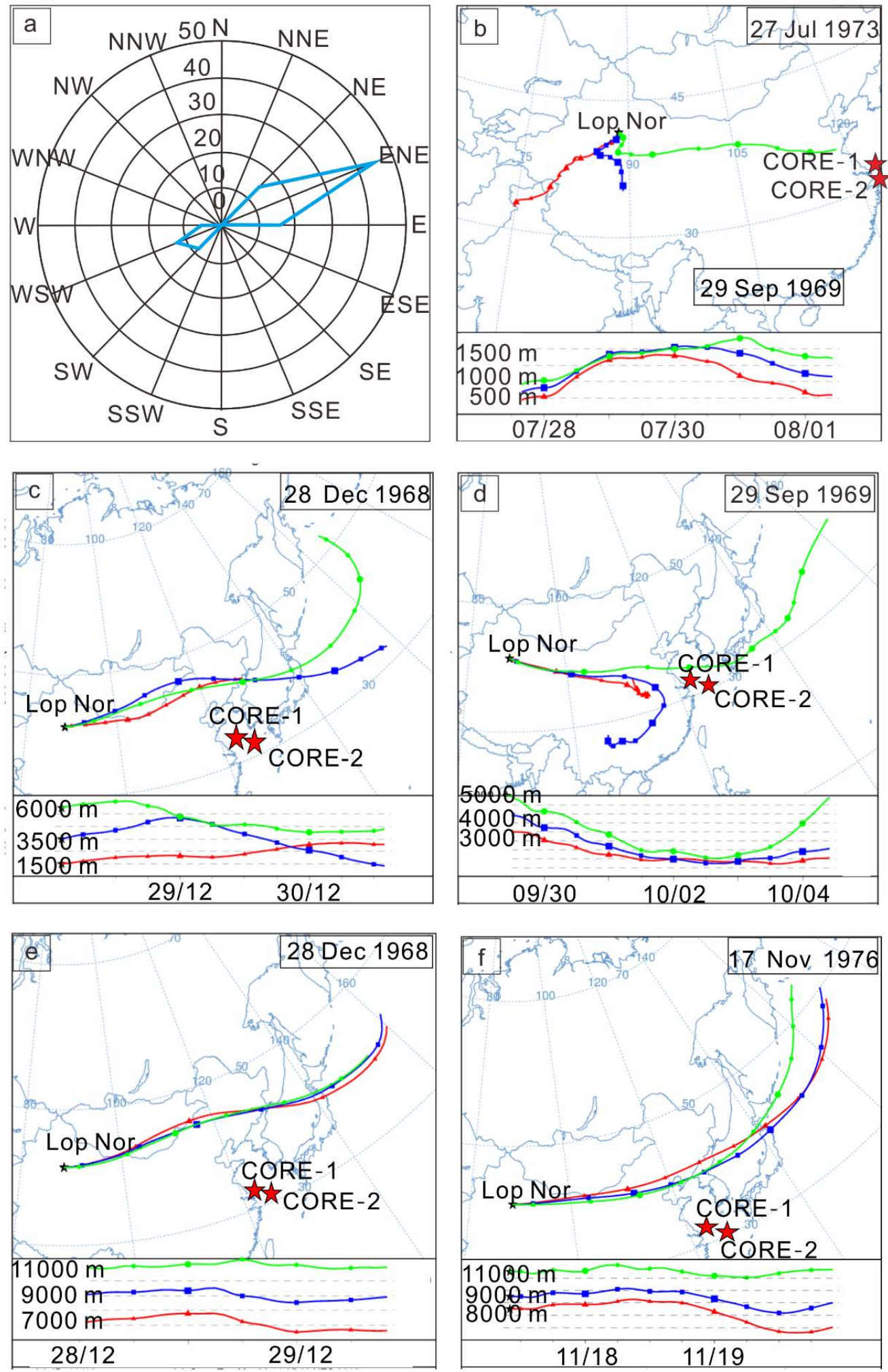